\title{
Quantitation of Avian RNA Tumor Virus Reverse Transcriptase by Radioimmunoassay
}

\author{
AMOS PANET, ${ }^{1}$ DAVID BALTIMORE,* AND TERUKO HANAFUSA \\ Center for Cancer Research, Massachusetts Institute of Technology, Cambridge, Massachusetts 02139, ${ }^{*}$ and The \\ Rockefeller University New York, New York 10021
}

Received for publication 19 February 1975

\begin{abstract}
A radioimmunoassay was developed that can detect and quantitate $3 \mathrm{ng}$ or more of the avian RNA tumor virus reverse transcriptase. The assay detected no antigenic sites in Rous sarcoma virus $\alpha$ virions or in virions of a murine RNA tumor virus. About 70 molecules of reverse transcriptase were found per virion of avian myeloblastosis virus with this assay or with an assay based on antibody inhibition of enzymatic activity. The assay detected about $270 \mathrm{ng}$ of enzyme per $\mathrm{mg}$ of cell protein in virus-producing cells; uninfected cells had much less antigenic material but contained some determinants able to displace radioactive antigen. No additional antigenic determinants on reverse transcriptase could be detected that were not found on the separated $\alpha$ subunit of the enzyme. Although sevenfold less sensitive than enzymatic activity as a measure of reverse transcriptase, the radioimmunoassay can detect antigen using small amounts of protein and in the presence of inhibitors.
\end{abstract}

Radioimmunoassay (RIA) is a powerful tool for detection and quantitation of the proteins of RNA tumor viruses $(4,20,22)$. The assay has been especially useful for studying the relative amounts of different viral proteins in productively infected cells or in nonproducing cells that express some viral genetic information $(5$, 21 ).

Three major classes of proteins are known to be encoded by the genomes of avian RNA tumor viruses (1): the internal low-molecular-weight proteins that derive from a 76,000 -dalton precursor (26); the glycoprotein of about 80,000 daltons (3); and the reverse transcriptase (24) that is apparently derived from a single 100,000 dalton subunit $(7,17)$. Although the internal proteins and the murine glycoprotein have been studied by RIA, the reverse transcriptase has previously been detected only by its DNA polymerase or RNase $\mathrm{H}$ activity $(2,24,28)$. We have now developed an RIA for the reverse transcriptase of avian RNA tumor viruses. With this assay, the enzyme can be detected in the presence of inhibitors and accurately quantitated independent of the vagaries of enzymatic assay.

\section{MATERIALS AND METHODS}

Viruses. Avian myeloblastosis virus (AMV) strain A was obtained from J. W. Beard through the Virus

${ }^{1}$ Present address: Department of Virology, Hebrew University, Hadassah Medical School, Jerusalem, Israel.
Cancer Program of the National Cancer Institute. Rous sarcoma virus $\alpha\left(\mathrm{RSV}_{\alpha}\right)$ was obtained as described previously (11). The Schmidt-Ruppin strain of RSV, subgroup A, was propagated on secondary chicken embryo fibroblasts obtained from SPAFAS (14). Moloney murine leukemia virus was grown as described previously (6). All viruses were purified on stepwise sucrose gradients (25) and banded again on 25 to $45 \%$ linear sucrose gradients (6).

Cells. Normal chicken embryo fibroblasts $\left(\mathrm{gs}^{-} \mathrm{h}^{-}\right)$ were characterized as described previously (5). Schmidt-Ruppin RSV subgroup A-infected chicken embryo fibroblasts and JLS V-9 cells were grown as described previously (ref. 14 and 6, respectively).

Cellular extracts. Confluent monolayers were harvested with trypsin and the cells were washed three to five times with phosphate-buffered saline, $\mathrm{pH} 7.4$ (PBS). Cell pellets were suspended in PBS containing $0.5 \%$ Nonidet P-40, $10 \mathrm{mM}$ dithiothreitol, and $10 \%$ glycerol and were homogenized with a glass Dounce homogenizer. The nuclei were removed by centrifugation for $4 \mathrm{~min}$ at $1,000 \times \mathrm{g}$. The supernatant was extracted three times with ether, dialyzed against PBS, and used for RIA.

Purification of reverse transcriptase. AMV 'reverse transcriptase was purified by chromatography on DEAE-Sephadex and phosphocellulose columns as described previously (25). The smaller subunit $(\alpha)$ was obtained as the peak eluting first from the phosphocellulose column (8). The holoenzyme $(\alpha, \beta)$ fraction from the phosphocellulose column was concentrated on a small phosphocellulose column and further purified by applying $1 \mathrm{ml}$ of the concentrated enzyme to a Sephadex G-100 column $(0.9$ by $60 \mathrm{~cm})$ equilibrated with $50 \mathrm{mM}$ Tris-hydrochloride ( $\mathrm{pH} \mathrm{8.0)}$, 
$0.2 \mathrm{M} \mathrm{KCl}, 0.01 \%$ Nonidet P-40, $0.5 \mathrm{mM}$ dithiothreitol, $0.1 \mathrm{mM}$ EDTA, and $20 \%$ glycerol. The reverse transcriptase activity, which eluted in the void volume of the column, was dialyzed extensively against $20 \mathrm{mM}$ potassium phosphate ( $\mathrm{pH} 7.5)-150$ $\mathrm{mM} \mathrm{KCl}$ and then dialyzed against $5 \mathrm{mM}$ potassium phosphate ( $\mathrm{pH} 7.5)$. It was then lyophilized and the residue was redissolved in $30 \mu \mathrm{l}$ of water. The purity of the reverse transcriptase was analyzed by sodium dodecyl sulfate-polyacrylamide gel electrophoresis (Fig. 1). The preparation was shown to consist of two subunits ( $\alpha$ and $\beta$ ) with a minor presumed contaminant between these two bands.

Iodination of reverse transcriptase. Iodination was carried out as described by Greenwood et al. (9). Reaction mixture $(35 \mu \mathrm{l})$ contained $5 \mu \mathrm{g}$ of reverse transcriptase, $500 \mu \mathrm{Ci}$ of $\mathrm{Na}^{125} \mathrm{I}$, and $4 \mu \mathrm{g}$ of chloramine $\mathrm{T}$ and was incubated for $15 \mathrm{~min}$ at $2 \mathrm{C}$. The product was separated from free $\mathrm{Na}^{125} \mathrm{I}$ by chromatog. raphy on a BioGel P-30 column. The iodinated enzyme was further purified by gel chromatography on a Sephadex G-200 column $(1.2$ by $70 \mathrm{~cm})$ equilibrated with $50 \mathrm{mM}$ Tris-hydrochloride ( $\mathrm{pH} \mathrm{8)}, 0.2 \mathrm{M}$ $\mathrm{KCl}, 0.02 \%$ Nonidet P-40, $0.5 \mathrm{mM}$ dithiothreitol, 0.1 $\mathrm{mM}$ EDTA, $20 \%$ glycerol, and $50 \mu \mathrm{g}$ of bovine serum albumin per $\mathrm{ml}$. The first radioactive peak eluted from the column was used for the RIA. All of the radioactivity could be precipitated with $5 \%$ trichloroacetic acid. This radioactive product was analyzed by sodium dodecyl sulfate-polyacrylamide gel electrophoresis and was shown by autoradiography to consist solely of the two subunits $(\alpha$ and $\beta)$ of reverse transcriptase.

RIA for reverse transcriptase. Reaction mixtures $(500 \mu \mathrm{l})$ contained PBS, $500 \mu \mathrm{g}$ of bovine serum albumin, $0.1 \%$ Nonidet $\mathrm{P}-40,0.25 \%$ normal rat serum, rat anti-AMV reverse transcriptase serum at the dilution indicated in the legends to the figures, and the sample tested for the presence of reverse transcriptase. After incubation for $1 \mathrm{~h}$ at $37 \mathrm{C}$, ${ }^{125}$ I-labeled reverse transcriptase was added $(10,000$ counts $/ \mathrm{min}$ ), and incubation continued for another hour at $37 \mathrm{C}$ followed by $18 \mathrm{~h}$ at $4 \mathrm{C}$. EDTA $(0.1 \mathrm{mM})$ and $30 \mu$ l of rabbit anti-rat immunoglobulin $G$ serum were added, followed by incubation for $1 \mathrm{~h}$ at $37 \mathrm{C}$ and $4 \mathrm{~h}$ at $4 \mathrm{C}$. The precipitate was collected by centrifugation, washed twice with PBS containing $1 \mathrm{mg}$ of bovine serum albumin per $\mathrm{ml}$ and $0.1 \%$ Nonidet P-40, and radioactivity was counted in a gamma ray counter. A 5\% background was subtracted, and $100 \%$ precipitation represents the amount of radiolabeled reverse transcriptase precipitated in the absence of any competing antigen.

DNA polymerase activity. Reaction mixtures $(100$

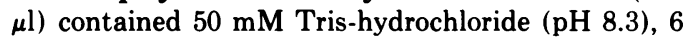
$\mathrm{mM} \mathrm{MgCl}{ }_{2}, 5 \mathrm{mM}$ dithiothreitol, $0.1 \mathrm{mM}\left[{ }^{3} \mathrm{H}\right.$ ]dGTP $(100$ counts/min per pmol), $2 \mu \mathrm{g}$ of poly $(\mathrm{C}), 0.5 \mu \mathrm{g}$ of oligo(dG) ${ }_{12-18}$, and reverse transcriptase as indicated. The mixtures were incubated at $37 \mathrm{C}$ and reactions were stopped by adding $5 \%$ trichloroacetic acid.

Protein concentrations were determined as described by Lowry et al. (16), with bovine serum albumin as standard protein.

Materials. $\mathrm{Na}^{125} \mathrm{I}$ and $\left[{ }^{2} \mathrm{H}\right] \mathrm{dGTP}$ were purchased

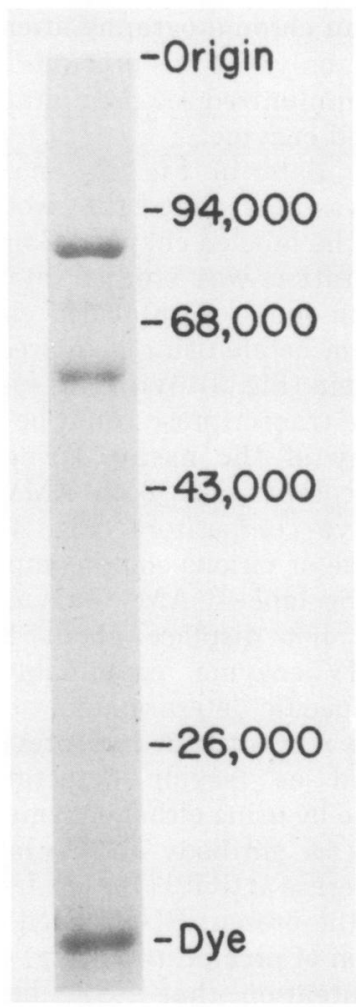

Fig. 1. Sodium dodecyl sulfate-gel electrophoresis of purified reverse transcriptase. AMV reverse transcriptase (Sephadex G-100 fraction) was subjected to electrophoresis on slab, $10 \%$ sodium dodecyl sulfatepolyacrylamide gel according to Laemli (15). The gel was stained with Coomassie blue. The following proteins were used as markers: phosphorylase a, mol wt 94,000; bovine serum albumin, mol wt 68,000; ovalbumin, mol wt 43,000; and chymotrypsinogen, mol wt 26,000.

from New England Nuclear Corp. Rabbit anti-rat immunoglobulin $G$ serum and normal rat serum were Miles Corp. products. Rat anti-AMV reverse transcriptase serum was a kind gift from R. Nowinski, University of Wisconsin, Madison.

\section{RESULTS}

Immunoprecipitation of reverse transcriptase and its inhibition. To develop an RIA for the AMV reverse transcriptase, we used a monospecific antiserum made in a rat against the enzyme. This serum had previously been shown to inhibit the enzymatic activities of the avian RNA tumor virus reverse transcriptase $(18,27)$. The ability of various dilutions of the antiserum to precipitate [125I]AMV reverse transcriptase is shown in Fig. 2. With high antiserum concentrations, $87 \%$ of the labeled enzyme was precipitated (if the Sephadex 
G-200 column chromatography after iodination was omitted, only $35 \%$ was precipitable). Serum from an unimmunized rat precipitated only $5 \%$ of the labeled enzyme.

From the data in Fig. 2, an amount of antiserum was determined that would precipitate $55 \%$ of the labeled enzyme. Competition of this precipitation was studied by incubating increasing amounts of unlabeled enzyme with the antiserum before using it to precipitate the labeled protein (Fig. 3). With this system, 3 to 5 ng of reverse transcriptase could be detected.

Specificity of the assay. Using disrupted virions for competition, both AMV and RSV were effective competitors (Fig. 4). Whereas AMV enzyme or virions could completely compete with the labeled AMV enzyme. RSV virions could not displace about $13 \%$ of the labeled AMV enzyme, presumably reflecting some type-specific determinants.

$\mathrm{RSV}_{\alpha}$ is a mutant that had previously been characterized as lacking detectable reverse transcriptase by using either enzymatic assay or competition for antibody able to inhibit AMV DNA polymerase activity $(10,18)$. Use of virions of $\mathrm{RSV}_{\alpha}$ in the present RIA showed no detectable inhibition of precipitation (Fig. 4), supporting the contention that $\mathrm{RSV}_{\alpha}$ lacks reverse transcriptase and demonstrating the ability of the RIA to distinguish among the virion proteins.

The antiserum used for precipitation showed no inhibition activity against the activity of murine leukemia virus reverse transcriptase in

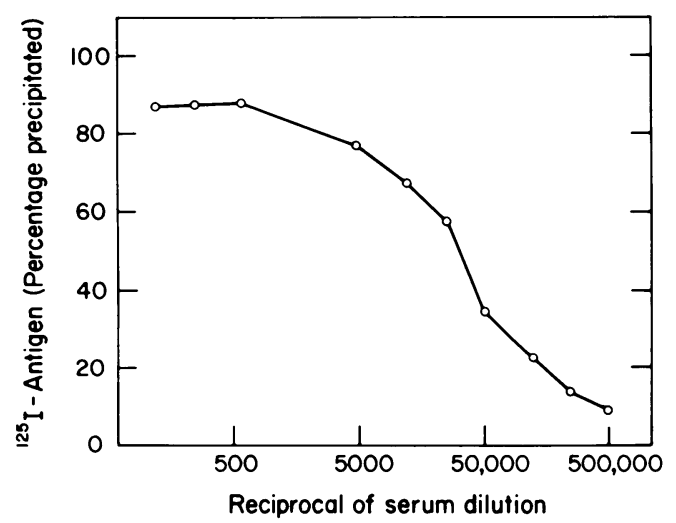

FIG. 2. Immunoprecipitation of ${ }^{125}$ I-labeled reverse transcriptase. Reactions were conducted as described in the text with ${ }^{125}$ I-labeled reverse transcriptase $(11,600$ counts/min $)$ and anti-reverse transcriptase serum at increasing dilutions as indicated. The mixtures were incubated for $1 \mathrm{~h}$ at $37 \mathrm{C}$ and $18 \mathrm{~h}$ at $4 \mathrm{C}$ before addition of rabbit anti-rat immunoglobulin $G$ (second antibody).

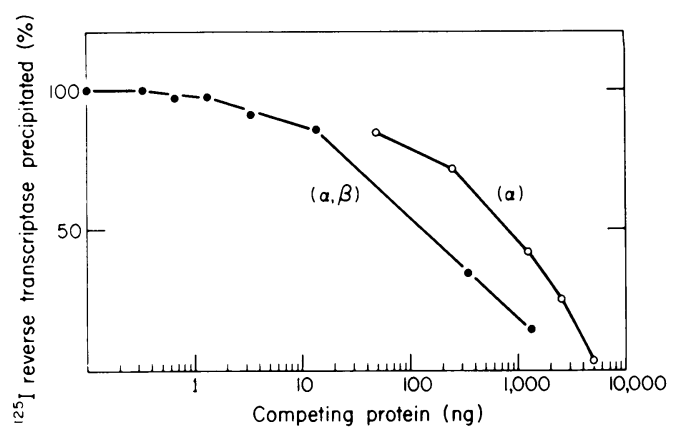

FIG. 3. Dose response of $A M V$ reverse transcriptase, $\alpha$ and $\alpha, \beta$ forms. Reactions were performed as described in the text with increasing amounts of the smaller subunit $(\alpha)$ (phosphocellulose fraction) or $\alpha, \beta$ (Sephadex G-100 fraction). Anti-reverse transcriptase serum was added at a 1:25,000 dilution, which gave $55 \%$ precipitation of ${ }^{125}$ I-labeled reverse transcriptase $(12,000$ counts/min $)$.

previous studies (18). To determine whether the murine enzyme would compete in the RIA, various amounts of disrupted virions of Moloney mouse leukemia virus were used as competitors; no inhibition of precipitation of the AMV enzyme was seen (Fig. 4).

Quantity of reverse transcriptase in virions. The ability of disrupted virions and homogeneous reverse transcriptase to compete in the RIA was determined (Fig. 5). From the displacement of the virion curve as compared with the purified enzyme curve, it appears that about $3.5 \%$ of the virion proteins are reverse transcriptase.

To verify the amount of reverse transcriptase in the virions, another immunologic approach was used. For this, rather than using the antibody to precipitate labeled enzyme, the antibody was used to inhibit the DNA polymerase activity of the enzyme and competition with this inhibition was used to quantitate the enzyme in unknown or standard preparations. The enzymatic activity of the unknown or standards was $100 \%$ inactivated with $N$-ethylmaleimide (NEM) before using them in the competition assay. NEM, which is a nonreversible inhibitor of the DNA polymerase activity (unpublished data), does not appear to affect the antigenic activity of the enzyme. Excess NEM was destroyed by dithiothreitol.

A dilution of 1:450 of the antiserum inhibited $86 \%$ of the DNA polymerase activity of a given amount of AMV reverse transcriptase using poly $(\mathrm{C})$-oligo $(\mathrm{dG})$ as a template primer. The curves of restoration of activity by competing NEM-inactivated pure enzyme or disrupted virions are shown in Fig. 6. From the scale 


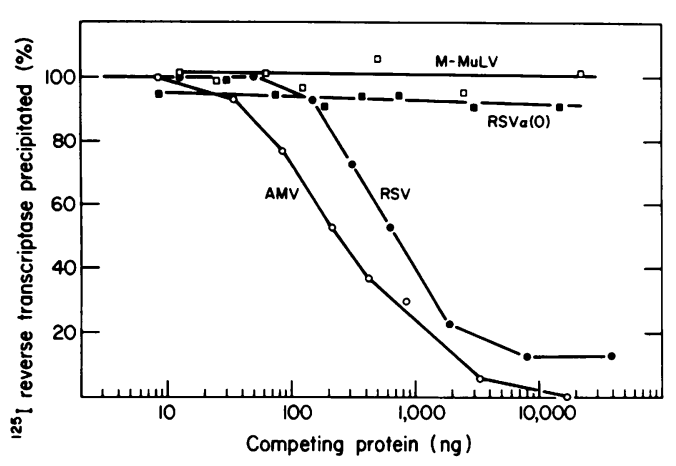

Fig. 4. Detection of reverse transcriptase in AMV and RSV. RIA was conducted as described in the text with serum against reverse transcriptase at a 1:37,500 dilution, which gave $50 \%$ precipitation of 9,100 counts/min of ${ }^{125} I$-labeled reverse transcriptase.

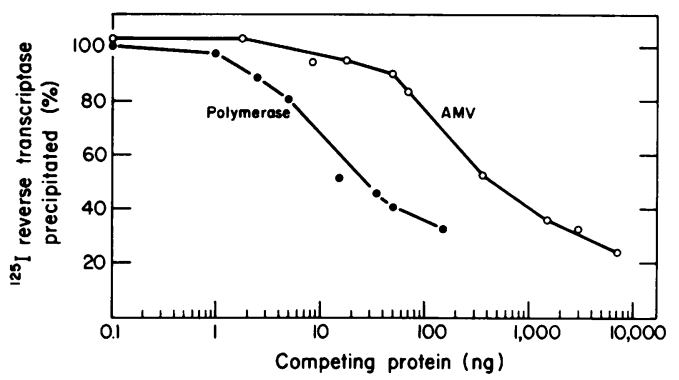

FIG. 5. Quantitation of reverse transcriptase in $A M V$ by RIA. Reactions were performed as described in the text with anti-AMV reverse transcriptase serum at a 1:25,000 dilution, which precipitated 53\% of ${ }^{126}$-labeled reverse transcriptase $(12,200$ counts $\min$.

change necessary to cause overlapping of the two restoration curves, about $2.2 \%$ of the weight of protein in the virion appears to be reverse transcriptase. This value agrees reasonably well with the $3.5 \%$ calculated by the RIA.

Detection of reverse transcriptase in crude cellular extracts. The RIA was applied to detect and quantitate reverse transcriptase in crude cellular extracts. Crude extract prepared from chicken embryo fibroblasts transformed by RSV competed effectively with ${ }^{125}$ I-labeled reverse transcriptase (Fig. 7) with a slope similar to that seen for virions of RSV (Fig. 4). Comparing the competition curves for pure enzyme and cell extract, the concentration of reverse transcriptase in the cells was $270 \mathrm{ng}$ per mg of cell protein. Extract from normal chicken embryo fibroblasts $\left(\mathrm{gs}^{-} \mathrm{h}^{-}\right)$could displace some ${ }^{126}$ I-labeled reverse transcriptase, but 10 times more protein from normal cells, as compared with RSV-transformed cells, was needed to displace $20 \%$ of ${ }^{125}$-labeled reverse transcriptase. Also, the competition curve for normal cells was shallower than that for transformed cells. Increasing amounts of crude extract made from the murine fibroblasts, JLS V-9 cells (29), failed to cross-react with anti-reverse transcriptase serum (Fig. 7).

Immunoreactivity of holoenzyme and active subunit. AMV reverse transcriptase has two subunits; $\alpha$ subunit contains both DNA polymerase and RNase $\mathrm{H}$ activity (8), and $\beta$ subunit has not been purified and is only known to increase the binding affinity of $\alpha$ to template - primer (19). The DNA polymerase activities of both $\alpha$ and $\alpha \beta$ were completely inhibited by the anti-AMV reverse transcriptase serum made against $\alpha \beta$ (Fig. 8). More significantly, when $\alpha$ and $\alpha \beta$ were used as competitors in the RIA with labeled $\alpha \beta, \alpha$ was able to completely

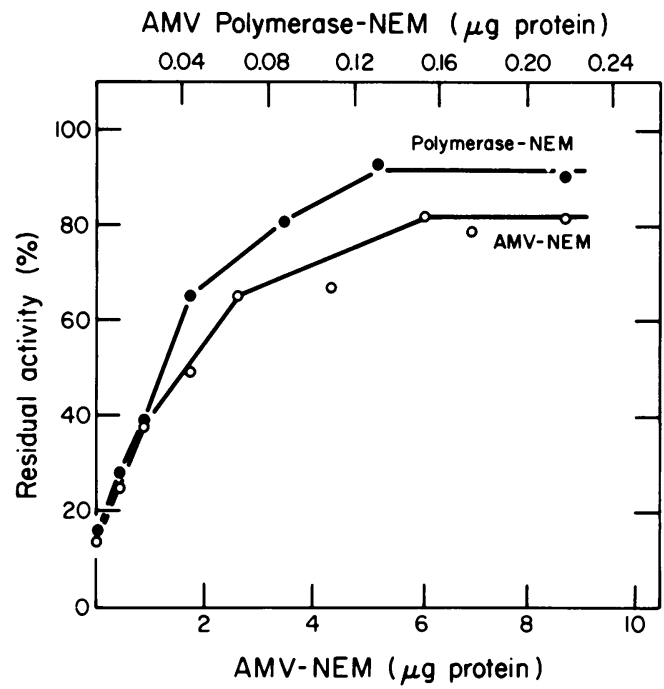

Fig. 6. Neutralization inhibition of DNA polymerase activity. The DNA polymerase activity in virus or purified reverse transcriptase was inactivated by incubation with $3 \mathrm{mM} \mathrm{NEM,} 50 \mathrm{mM}$ Tris-hydrochloride, $\mathrm{pH} 8.0,1 \mathrm{mg}$ of bovine serum albumin per $\mathrm{ml}$, and $1 \%$ Nonidet $P-40$. After $15 \mathrm{~min}$ at $4 \mathrm{C}$, dithiothreitol $(20 \mathrm{mM})$ was added to destroy excess NEM. Increasing amounts of antigen-NEM were reacted with anti-reverse transcriptase serum at a 1:450 dilution in mixtures $(45 \mu l)$ containing $10 \mathrm{mM}$ Trishydrochloride, pH 8.0, $150 \mathrm{mM} \mathrm{KCl}, 0.5 \mathrm{mg}$ of bovine serum albumin per $\mathrm{ml}$, and $10 \%$ glycerol. After $20 \mathrm{~min}$ of incubation at $37 C$, active purified $A M V$ reverse transcriptase (25 $\mathrm{ng}$ in $5 \mu \mathrm{l}$ ) was added and incubation was continued for another $20 \mathrm{~min}$ at $37 \mathrm{C}$. The residual DNA polymerase activity in the mixtures was determined by adding $50 \mu \mathrm{l}$ of a mixture of all the components needed for assaying DNA polymcrase activity (see text). 


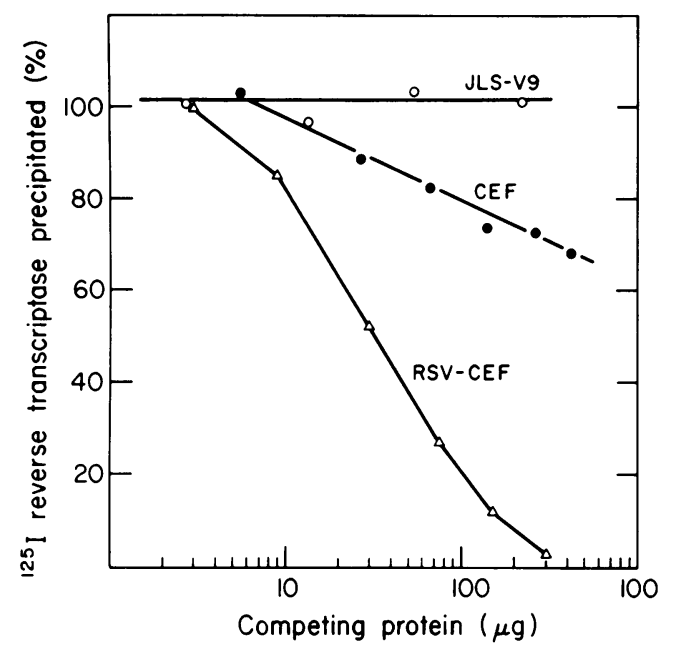

Fig. 7. Reverse transcriptase in crude cellular extracts. RIA with crude extracts was conducted as described in the text with anti-reverse transcriptase serum at a 1:20,600 dilution, which precipitated $42 \%$ of ${ }^{125}$ I-labeled reverse transcriptase $(8,200$ counts/ $\min$ ).

displace radiolabeled $\alpha \beta$ from the precipitate (Fig. 3). A higher amount of $\alpha$ protein than $\alpha \beta$ proteins was needed to give complete competition, possibly due to either the relative impurity of $\alpha$ or partial denaturation of $\alpha$ during preparation. Rechromatography of $\alpha$ preparations has shown less than $6 \%$ of $\alpha \beta$ contamination, so the competition seen in Fig. 3 could not be due to $\alpha \beta$ in the $\alpha$ preparations. We conclude from these results that there are no antigenic determinants for precipitation of $\alpha \beta$ that are not also present on $\alpha$ alone.

Comparison of radioimmunoassay to enzymatic assay of DNA polymerase. To compare the sensitivity of the RIA to the direct determination of reverse transcriptase by DNA polymerase assay, the amount of enzyme needed for a $20 \%$ competition in the RIA was compared with the amount required to catalyze the incorporation of $5 \mathrm{pmol}$ of dGMP with poly $(\mathrm{C}) \cdot$ oligo $(\mathrm{dG})$ as the template-primer. The enzymatic assay was sevenfold more sensitive for the pure enzyme (Table 1). In the disrupted virions, the enzymatic assay was ninefold more sensitive (Table 1), indicating that purification of the enzyme does not lead to marked inactivation or activation.

The advantage of RIA over enzyme assay comes when cell extracts are being studied. Inhibitors of DNA polymerase activity in crude extracts can mask or alter enzyme activity in extracts, but the immunologic assay is not affected. We have previously used enzyme as- says after phosphoscellulose chromatography to quantitate in vivo reverse transcriptase (2), but this requires a few milligrams of protein whereas the RIA of RSV-transformed cells can be carried out with $11 \mu \mathrm{g}$ of cell protein (Table $1)$.

\section{DISCUSSION}

By using a rat antiserum made against the AMV reverse transcriptase and ${ }^{125}$ I-labeled pure enzyme, an RIA for reverse transcriptase has been developed that can detect 3 to $5 \mathrm{ng}$ of the enzyme. This level of sensitivity is comparable with that of RIAs used to detect other viral proteins such as p30 and gp70 $(4,22)$.

Monospecific antiserum against AMV reverse transcriptase was shown by Nowinski et al. (18) to inhibit the DNA polymerase activities of the enzymes from both AMV and RSV, suggesting that the active sites of the two enzymes were similar. By using the RIA for analysis of reverse transcriptase, we confirmed the cross-reaction of the two enzymes, but we were also able to detect a small proportion of antigenic sites on the AMV enzyme not found on the RSV enzyme. The extensive homology between AMV and RSV reverse transcriptase enabled us to use the same RIA for the detection of both enzymes in crude extracts. When assaying RSV-infected

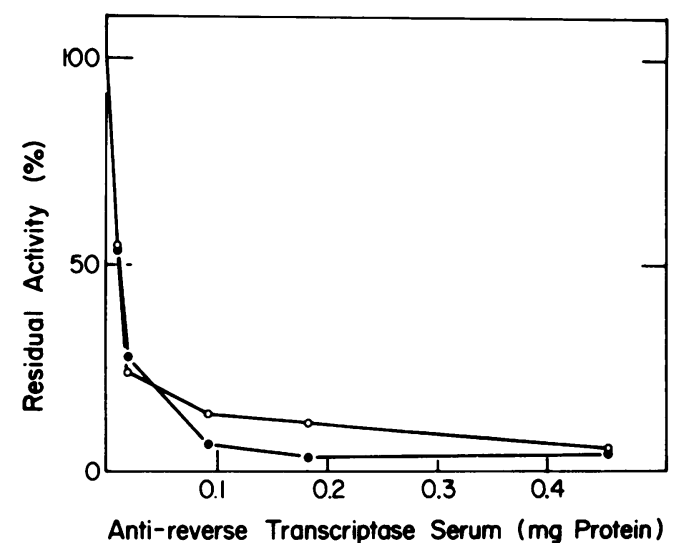

Fig. 8. Inhibition of DNA polymerase activity in $\alpha$ and $\alpha, \beta$ forms of reverse transcriptase by monospecific antibodies. The reactions were conducted in two steps: (i) neutralization of reverse transcriptase by antibodies; and (ii) assay for residual DNA polymerase activity. The initial reaction mixtures $(50 \mu l)$ contained $10 \mathrm{mM}$ Tris-hydrochloride, pH 8.3, $150 \mathrm{mM}$ $\mathrm{KCl}, 20 \%$ glycerol, $50 \mu \mathrm{g}$ of bovine serum albumin, 50 units of enzyme $\alpha$ subunit (O) or $\alpha, \beta$ form ( $(\Theta)$, and rat anti-AMV reverse transcriptase serum. Incubation for $10 \mathrm{~min}$ at room temperature was followed by assay of the residual polymerase activity as described in the text. 
TABLE 1. Comparison of RIA to DNA polymerase assay for detection of reverse transcriptase

\begin{tabular}{|c|c|c|c|}
\hline \multirow{2}{*}{ Source of enzyme } & \multicolumn{2}{|c|}{$\begin{array}{l}\text { Amt of protein (ng) } \\
\text { detected by: }\end{array}$} & \multirow{2}{*}{ Ratio } \\
\hline & RIA $^{a}$ & $\begin{array}{l}\text { DNA poly- } \\
\text { merase assay }^{b}\end{array}$ & \\
\hline $\begin{array}{l}\text { Purified reverse tran- } \\
\text { scriptase } \ldots \ldots \ldots \ldots \\
\text { AMV } \ldots \ldots \ldots \ldots \ldots \ldots \\
\text { RSV } \ldots \ldots \ldots \ldots \ldots \\
\text { RSV-transformed } \\
\text { CEF extract }{ }^{c} \ldots \ldots\end{array}$ & $\begin{array}{r}5 \\
80 \\
180 \\
\\
11,500\end{array}$ & $\begin{array}{c}0.7 \\
8.5 \\
20.5 \\
\\
\text { No activity }\end{array}$ & $\begin{array}{l}7 \\
9 \\
9\end{array}$ \\
\hline
\end{tabular}

${ }^{a}$ Amount of protein needed for displacement of $20 \%$ of ${ }^{125}$ I-labeled reverse transcriptase in RIA (see Fig. 4 and 7).

- Amount of protein needed to catalyze the incorporation of $5 \mathrm{pmol}$ of $\left[{ }^{3} \mathrm{H}\right.$ ]dGTP (500 counts/min) in 60 min under standard conditions (see text).

c CEF, Chicken embryo fibroblast.

cells (Fig. 7), the AMV type-specific determinants were not evident, suggesting that they may be present on proteins in infected cells but not on the DNA polymerase packaged in virions of RSV.

By using the antibody to reverse transcriptase either in the RIA or in an assay based on inhibition of enzyme activity, the amount of enzyme in virions was assessed. The enzyme comprised about $3 \%$ of the AMV virion protein by either assay. The molecular weight of the enzyme is about 160,000 (13); assuming that the virion contains $3.8 \times 10^{8}$ daltons of protein (23), there would be about 70 molecules of enzyme per virion. Schmidt-Ruppin RSV virions appear to have about $40 \%$ of the enzyme found in AMV (Table 1); the difference may or may not be real, however, because plasmaderived AMV is being compared with RSV from chicken embryo cell cultures. Kacian et al. (13) estimated that AMV virions have only 5 to 17 molecules of reverse transcriptase based on the degree of purification of the enzyme necessary to reach homogeneity. The difference between their estimate and ours could be a result of the different methods used or of the preparations of virus used. Whatever the explanation, it is apparent that many molecules of reverse transcriptase are present in each virion.

The level of reverse transcriptase in the infected cells we studied was about $270 \mathrm{ng}$ per $\mathrm{mg}$ of cell protein. This is much less than the values reported for $\mathrm{p} 30$ and other virion proteins in infected cells (4), especially when corrected to moles of protein per cell. Although these studies must all be done on the same materials to be certain of the ratio of the various proteins, the data suggest that many fewer molecules of reverse transcriptase are formed than of p30, p19, and p15 (all three of which are apparently derived from a single 76,000-dalton precursor).

We were able to detect material that inhibited the RIA in uninfected cells (Fig. 7). These cells were $\mathrm{gs}^{-} \mathrm{h}^{-}$, but all uninfected chick cells studied by Chen et al. (5) have had p30, so the inhibition could be due to reverse transcriptase in uninfected cells. We have recently detected an activity that could be reverse transcriptase in uninfected cells using poly $(\mathrm{C}) \cdot$ oligo $(\mathrm{dG})$ as template-primer to direct the synthesis of poly (dG) (unpublished data). Further study of this question is required.

AMV reverse transcriptase has been shown to consist of two polypeptides, $\alpha$ and $\beta$, with molecular weights of 60,000 and 100,000 , respectively. Reverse transcriptase isolated from virions can be separated by column chromatography into two enzymatically active forms-the smaller subunit $(\alpha)$ and the holoenzyme $(\alpha, \beta)$ (8). The two forms have similar enzymatic activities but differ in their binding affinity to template -primer complex (19). The ability of antiserum against the holoenzyme to inhibit the activity of $\alpha$ confirms the identity of the active site of these two forms of enzyme. Furthermore, the ability of the $\alpha$ subunit to displace all of the ${ }^{125}$ I-labeled $\alpha, \beta$ in the RIA suggests that $\alpha$ contains all of the antigenic determinants of $\alpha$, $\beta$ form. A likely explanation for this phenomenon is that $\beta$ is very similar to $\alpha$. Such an interpretation would agree with the suggestion that $\alpha$ may be a proteolytic cleavage product of $\beta$ (17) and the discovery that there are amino acid sequence similarities between $\alpha$ and $\beta$ (7).

Even though the RIA for reverse transcriptase is almost 10 -fold less sensitive than assay of DNA polymerase activity (Table 1 ), the ability to quantitate amounts of protein rather than catalytic activity has certain advantages. Some of these are evident from the studies reported here, but the major advantage will come from analysis of intracellular forms of the enzyme.

\section{ACKNOWLEDGMENTS}

This investigation was supported by a Public Health Service contract from the Virus Cancer Program of the National Cancer Institute and Public Health Service grants CA 14051 and CA 14936 from the National Cancer Institute. D. B. was supported by a Research Professorship from the American Cancer Society.

We wish to thank R. Nowinski and J. W. Beard for materials.

\section{LITERATURE CITED}

1. Baltimore, D. 1974. Tumor viruses: 1974. Cold Spring Harbor Symp. Quant. Biol. 39:1187-1200. 
2. Baltimore, D., R. McCaffrey, and D. F. Smoler. 1973. Properties of reverse transcriptase, p. 51-59. In C. F. Fox and W. S. Robinson (ed.), Virus research, vol. 17, Academic Press Inc., New York.

3. Bolognesi, D. P., and H. Bauer. 1970. Polypeptides of avian RNA tumor viruses. I. Isolation and physical and chemical analysis. Virology 42:1097-1112.

4. Chen, J. H., and H. Hanafusa. 1974. Detection of a protein of avian leukoviruses in uninfected chick cells by radioimmunoassay. J. Virol. 13:340-346.

5. Chen, J. H., W. S. Hayward, and H. Hanafusa. 1974. Avian tumor virus proteins and ribonucleic acid in uninfected chicken embryo cells. J. Virol. 14:1419-1429.

6. Fan, H., and D. Baltimore. 1973. RNA metabolism of murine leukemia virus: detection of virus specific RNA sequences in infected and uninfected cells and identification of virus specific messenger RNA. J. Mol. Biol. 80:93-117.

7. Gibson, W., and I. M. Verma. 1974. Studies on the reverse transcriptase of RNA tumor viruses. Structural relatedness of two subunits of avian RNA tumor viruses. Proc. Natl. Acad. Sci. U.S.A. 71:4991-4994.

8. Grandgenett, D. P., G. F. Gerard, and M. Green. 1973. A single subunit from avian myeloblastosis virus with both RNA directed DNA polymerase and ribonuclease H activity. Proc. Natl. Acad. Sci. U.S.A. 70:230-234.

9. Greenwood, F. C., W. M. Hunter, and J. S. Glover. 1963. The preparation of ${ }^{138} \mathrm{I}$ labeled human growth hormone of high specific radioactivity. Biochem. J. 89:114-123.

10. Hanafusa, H., D. Baltimore, D. Smoler, K. F. Watson, A. Yaniv, and S. Spiegelman. 1972. Absence of polymerase protein in virions of alpha type Rous sarcoma virus. Science 177:1188-1191.

11. Hanafusa, H., and T. Hanafusa. 1971. Noninfectious RSV deficient in DNA polymerase. Virology 43:313-316.

12. Hurwitz, J., and J. P. Leis. 1972. RNA-dependent DNA polymerase activity of RNA tumor viruses. I. Directing influence of DNA in the reaction. J. Virol. 9:116-129.

13. Kacian, D. L., K. F. Watson, A. Burny, and S. Spiegelman. 1971. Purification of the DNA polymerase of avian myeloblastosis virus. Biochim. Biophys. Acta 246:365-383.

14. Kawai, S., and H. Hanafusa. 1972. Genetic recombination with avian tumor virus. Virology 49:37-41.

15. Laemmli, U. K. 1970. Cleavage of structural proteins during the assembly of the head of bacteriophage $T_{4}$. Nature (London) 227:680-685.

16. Lowry, O. H., N. J. Rosebrough, A. L. Farr, and R. J. Randall. 1951. Protein measurement with the Folin phenol reagent. J. Biol. Chem. 193:265-275.

17. Moelling, K. 1974. Reverse transcriptase and RNase H present in a murine virus and in both subunits of an avian virus. Cold Spring Harbor Symp. Quant. Biol. 39:969-973.

18. Nowinski, R. C., K. F. Watson, A. Yanıv, and S. Spiegelman. 1972. Serological analysis of the deoxyribonucleic acid polymerase of avian oncornaviruses. II. Comparison of avian deoxyribonucleic acid polymerases. J. Virol. 10:959-964.

19. Panet, A., I. M. Verma, and D. Baltimore. 1974. Role of the subunits of the avian RNA tumor virus reverse transcriptase. Cold Spring Harbor Symp. Quant. Biol. 39:919-923.

20. Stephenson, J. R., S. R. Tronick, and S. A. Aaronson. 1974. Analysis of type specific antigenic determinants of two structural polypeptides of mouse RNA C-type viruses. Virology 58:1-8.

21. Stephenson, J. R., R. Wilsnack, and S. A. Aaronson. 1973. Radioimmunoassay for avian C-type virus groupspecific antigen: detection in normal and virustransformed cells. J. Virol. 11:893-899.

22. Strand, M., and J. T. August. 1973. Structural proteins of oncogenic ribonucleic acid viruses. J. Biol. Chem. 248:5627-5633.

23. Stromberg, K., N. E. Hurley, N. L. Davis, R. R. Rueckert, and E. Fleissner. 1974. Structural studies of avian myeloblastosis virus: comparison of polypeptides in virion and core component by dodecyl sulfate-polyacrylamide gel electrophoresis. J. Virol. 13:513-528.

24. Temin, H. M., and D. Baltimore. 1972. RNA-directed DNA synthesis and RNA tumor viruses, p. 129-186. In K. M. Smith and M. A. Lauffer (ed.), Advances in virus research, vol. 17. Academic Press Inc., New York.

25. Verma, I. M., and D. Baltimore. 1973. Purification of the RNA directed DNA polymerase from avian myeloblastosis virus and its assay with polynucleotide templates. Methods Enzymol. 29:125-131.

26. Vogt, V. M., and R. Eisenman. 1973. Identification of a large polypeptide precursor of avian oncormavirus proteins. Proc. Natl. Acad. Sci. U.S.A. 70:1734-1738.

27. Watson, K. F., R. C. Nowinski, A. Yaniv, and S. Spiegelman. 1972. Serological analysis of the deoxyribonucleic acid polymerase of avian oncornaviruses. I. Preparation and characterization of monospecific antiserum with purified deoxyribonucleic acid polymerase. J. Virol. 10:951-958.

28. Weissbach, A., A. Bolden, R. Muller, H. Hanafusa, and T. Hanafusa. 1972. Deoxyribonucleic acid polymerase activities in normal and leukovirus-infected chicken embryo cells. J. Virol. 10:321-327.

29. Wright, B. S., P. A. O'Brien, G. P. Shibley, S. A. Mayyasi, and J. C. La Fargues. 1967. Infection of an established bone marrow cell line JLS V-9 with Rauscher and Moloney murine leukemia viruses. Cancer Res. 27:1672-1677. 